
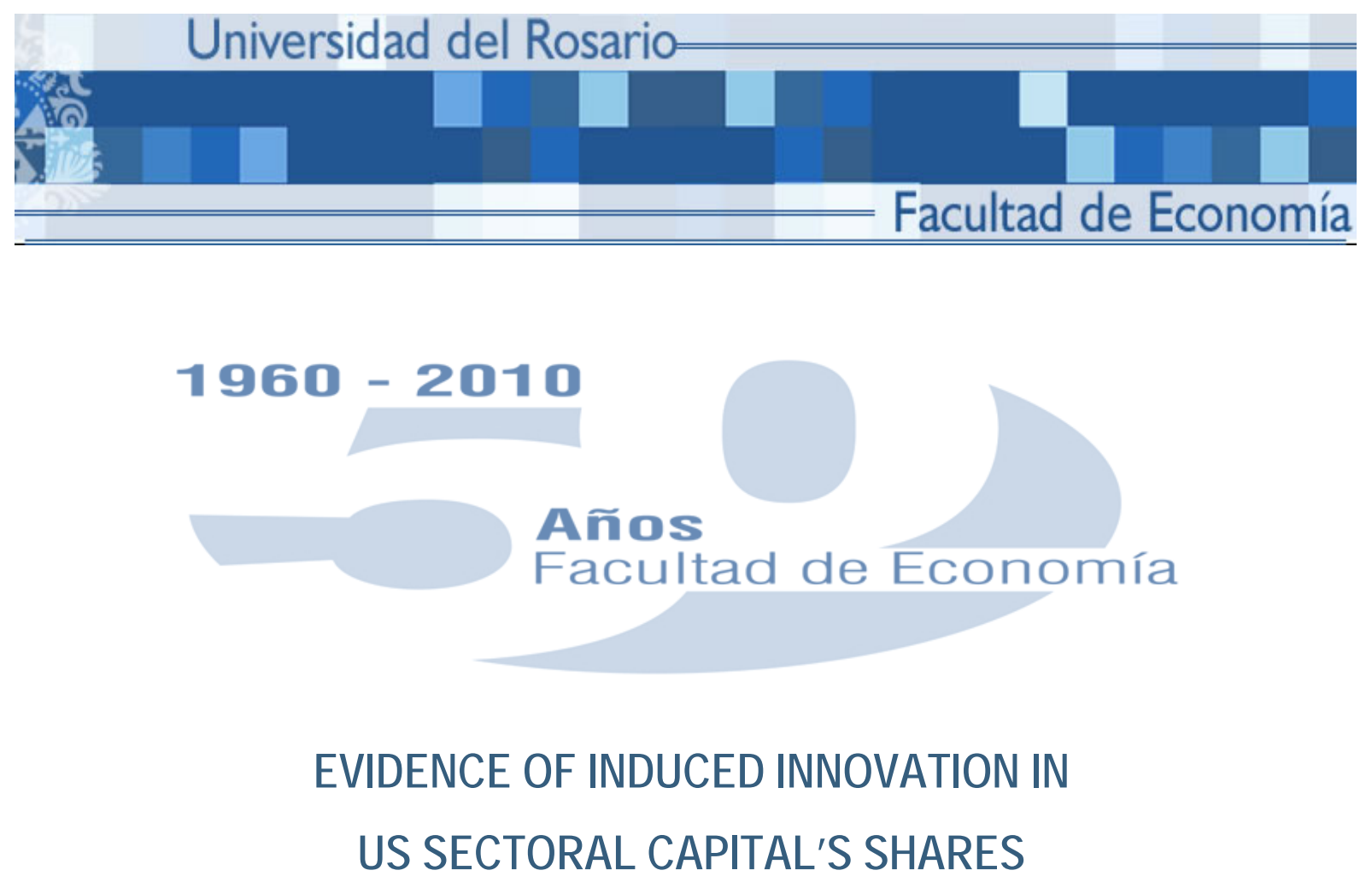

Andrew T. Young

Hernando Zuleta

Andrés F. García-Suaza

No. 80

Marzo 2010 


\title{
Evidence of Induced Innovation in US Sectoral Capital's Shares
}

\author{
Andrew T. Young ${ }^{*}$ \\ College of Business and Economics \\ Division of Economics and Finance \\ West Virginia University \\ Morgantown, WV 26505-6025 \\ Andrew.Young@mail.wvu.edu \\ Hernando Zuleta \\ Department of Economics \\ Universidad del Rosario \\ American University in Bulgaria \\ hernando.zuleta@gmail.com \\ Andrés F. García-Suaza \\ Facultad de Economía \\ Universidad del Rosario - Bogotá \\ andres.garcia66@urosario.edu.co
}

JEL Codes: O31, O47, E25, E23

Keywords: induced innovation, biased technical change, capital's share, labor's share, elasticity of substitution

\footnotetext{
${ }^{*}$ Corresponding author.
} 


\section{Evidence of Induced Innovation in US Sectoral Capital's Shares}

Abstract: We use annual data on capital's share and relative factor prices from 35 US industries from 1960 to 2005 to test the induced innovation hypothesis. We derive, from a production function framework, testable implications for the effect of contemporaneous and lagged factor price ratios on capital's share of production. The predicted effect is positive or negative depending on the elasticity of substitution between labor and capital. From panel regressions, the estimated effect of the contemporaneous factor price ratio implies an elasticity of substitution that is less than unity, consistent with the consensus from the literature. Based on this, our negative estimated effects for lagged price ratios are both statistically significant and consistent with the induced innovation hypothesis.

JEL Codes: O31, O47, E25, E23

Keywords: induced innovation, biased technical change, capital's share, labor's share, elasticity of substitution 


\section{Introduction}

Capital's share of aggregate income/output is constant. This is one of Kaldor's (1961) stylized facts of economic growth. It is the stylized fact which, to a large extent, supports the widespread use of the Cobb-Douglas (1928) production function in macroeconomics. Alternatively, if capital's share is constant and factor prices are equal to marginal productivities, then the elasticity of output with respect to capital is constant and the Cobb-Douglas production function is a reasonable approximation of the aggregate production function. ${ }^{1}$

However, at the sectoral level, capital's shares fluctuate markedly (e.g., Young (2010) for the US; Zuleta et al. (2010) for Columbia; Garrido-Ruiz (2005) for Spain). Solow (1958) and Young (2010) argue that, in the US, that the evolution of aggregate capital's share is not surprisingly stable given the sectoral fluctuations. ${ }^{2}$ There have is also evidence that the capital's shares of many economies, if measured properly, have clear trends (e.g., Zuleta (2008b), Zuleta et al. (2008) and Sturgill (2009)). The fluctuations and trends and economy's capital's shares are not exogenous givens; they are indicative of underlying economic phenomena. One potential underlying phenomenon is induced innovation. We argue here that, for the US from 1960 to 2005, evidence suggests that induced innovation is a significant determinant of the evolution of sectoral capital's shares at the roughly 2-digit SIC sector level.

The idea of induced innovation was popularized by a series of authors including Kennedy (1964, 1973), Samuelson (1965), Ahmad (1966), Drandakis and Phelps (1966), Weizsäcker (1966) and Binswanger (1974). Their models predict that a decrease in the relative cost of a

\footnotetext{
${ }^{1}$ A Cobb-Douglas is a sufficient but not necessary condition for balanced growth; the necessary condition is laboraugmenting technical change (Uzawa (1961) and Jones and Scrimgeour (2008)). However, balanced growth does imply that aggregate production possibilities asymptotically behave like a Cobb-Douglas.

${ }^{2}$ Young (2010) demonstrates that the largest component of US sectoral labor's shares variation is independent across sectors. Therefore, it is not surprising that the aggregate share's variance is considerably smaller than the average sectoral share variance. Solow (1958) makes the same argument but lacks the quality of data available to Young.
} 
factor induces innovations biased towards more intensive use of that factor. (Hence this literature is also referred to as the biased literature). In the longer run, such induced innovation can significantly affect the distribution of income across factors. In the shorter-run, biased innovations may contribute to macroeconomic fluctuations (Young, 2004). The results presented here highlight the importance of research into the preceding.

The theory of induced innovations has been recently revisited by several authors including Zeira (1998), Acemoglu (2002), Boldrin and Levine (2002), Funk (2002), Zuleta (2008a) and Zuleta and Young (2010). However, while these models are consistent with observed trends in factor shares and prices, there is a near absence of empirical evidence explicitly supporting the induced innovation hypothesis. (Zuleta et al. (2010) is one exception using Colombian data.)

In this we formally derive testable implications of induced innovation in a production framework and then bring those implications to the US data. We utilize the Jorgenson (2007) KLEM data based on 35 US sectors. This is an input-output database and is described in Jorgenson et al. (1987) and Jorgenson and Stiroh (2000). For our purposes, the database provides the prices and quantities are productive factors - capital and labor, in particular - as well as sectoral value-added.

The paper proceeds as follows. Section 2 introduces the production function framework and derives the testable implications. Section 3 describes our calculation of capital's shares, factor ratios, and factor price ratios from the KLEM data. Results based on the empirical model derived from Section 2 are reported and discussed in Section 4. Section 5 concludes. 


\section{Induced (Biased) Innovations in a Production Function Framework}

Consider a CES production function where capital and labor are used to produce output:

$$
Y=Z\left[\theta\left(A_{K} K\right)^{\gamma}+(1-\theta)\left(A_{L} L\right)^{\gamma}\right]^{\frac{1}{\gamma}} .
$$

In (1) the only constant we will assume is $\gamma$ implying a constant elasticity of substitution, $\sigma=\frac{1}{1-\gamma}$. No exact definition of biased technical change has been established. ${ }^{3}$ For our purposes, biased technical change may be represented by factor-augmentation ( $A_{K}$ or $A_{L}$ growth) and/or changes in the effective factor weighting parameter $(\theta){ }^{4}$

If factor prices are equated to the factors' marginal products in production, then the marginal product of labor and marginal product of capital are, respectively,

$$
\begin{aligned}
& \left.w=Z\left[\theta\left(A_{K} K\right)^{\gamma}+(1-\theta)\left(A_{L} L\right)^{\gamma}\right]^{1}-1-\theta\right) A_{L}^{\gamma} L^{\gamma-1} ; \\
& r=Z\left[\theta\left(A_{K} K\right)^{\gamma}+(1-\theta)\left(A_{L} L\right)^{\gamma}\right]^{1}-1 \theta A_{K}^{\gamma} K^{\gamma-1} .
\end{aligned}
$$

Note that the ratio of marginal products (factor prices) is,

$$
\frac{r}{w}=\frac{\theta}{1-\theta}\left(\frac{A_{K}}{A_{L}}\right)^{\gamma}\left(\frac{K}{L}\right)^{\gamma-1}
$$

It follows that labor's share is,

$$
(1-\alpha)=\frac{1}{1+\frac{r K}{w L}}
$$

where

\footnotetext{
${ }^{3}$ Biased technical change is generally any change that is not neutral in some specified way. While Hicks-neutral (represented by a scalar on the production function) and Harrod-neutral (labor-augmenting) are the most oft evoked types of neutrality, numerous types of neutral technical change have been defined (Sato and Beckman, 1968).

${ }^{4}$ Factor-augmenting technical change will not affect factor shares if the elasticity of substitution is unity (i.e., the Cobb-Douglas case).
} 


$$
\frac{r}{w} \frac{K}{L}=\left(\frac{\theta}{1-\theta}\right)^{\frac{1}{1-\gamma}}\left(\frac{A_{K}}{A_{L}}\right)^{\frac{\gamma}{1-\gamma}}\left(\frac{r}{w}\right)^{-\frac{\gamma}{1-\gamma}} .
$$

Capital's share is then $\alpha$. Substituting (3) into (2) yields,

$$
(1-\alpha)=\frac{1}{1+\left(\frac{\theta}{1-\theta}\right)^{\frac{1}{1-\gamma}}\left(\frac{A_{K}}{A_{L}}\right)^{\frac{\gamma}{1-\gamma}}\left(\frac{r}{w}\right)^{-\frac{\gamma}{1-\gamma}}},
$$

and then,

$$
\frac{\alpha}{1-\alpha}=\left(\frac{\theta}{1-\theta}\right)^{\frac{1}{1-\gamma}}\left(\frac{A_{K}}{A_{L}}\right)^{\frac{\gamma}{1-\gamma}}\left(\frac{r}{w}\right)^{-\frac{\gamma}{1-\gamma}} .
$$

Taking natural logs of the above equation results in,

$$
\ln \left(\frac{\alpha}{1-\alpha}\right)=\left(\frac{1}{1-\gamma}\right) \ln \left(\frac{\theta}{1-\theta}\right)+\left(\frac{\gamma}{1-\gamma}\right) \ln \left(\frac{A_{K}}{A_{L}}\right)-\left(\frac{\gamma}{1-\gamma}\right) \ln \left(\frac{r}{w}\right)
$$

Equation (4) is linear and states that the distribution of income across factors is determined by the contemporaneous ratio of factor prices and the state of technology (represented by the first and second right-hand-side terms). The right-hand-side of (4), $\ln \left(\frac{\alpha}{1-\alpha}\right)$, is monotonically increasing in capital's share. The elasticity of substitution parameter $(\gamma)$ determines the extent to which both factor-augmenting technical change and changes in the capital to labor ratio affect capital's share. ${ }^{5}$

Based on the idea of induced innovation, we hypothesize that the state of technology, $\left(\frac{1}{1-\gamma}\right) \ln \left(\frac{\theta}{1-\theta}\right)+\left(\frac{\gamma}{1-\gamma}\right) \ln \left(\frac{A_{K}}{A_{L}}\right)$, is a function of lagged factor prices. (Presumably, current

\footnotetext{
${ }^{5}$ Note that $Z$ does not appear in (4) because it is a Hicks-neutral technology shifter and will not affect the income distribution.
} 
factor prices cannot bias the state of technology today since induced innovation takes time.) We specify,

$$
\left(\frac{1}{1-\gamma}\right) \ln \left(\frac{\theta_{t}}{1-\theta_{t}}\right)+\left(\frac{\gamma}{1-\gamma}\right) \ln \left(\frac{A_{K t}}{A_{L t}}\right)=\delta+\sum_{j=1}^{J} \beta_{i} \ln \left(\frac{r_{j-i}}{w_{j-i}}\right)+\varepsilon_{t}
$$

where the $\beta$ s are parameters and $\delta$ and $\varepsilon$ can be interpreted as the effect of biased but not induced technical change and/or omitted lagged factor price ratio terms. Note that $\delta$, interpreted this way, may be a function of time if there are trends in technology. (This is a possibility that we include and test in the empirical analysis below.) Given (5) we can restate (4) as,

$$
\ln \left(\frac{\alpha_{t}}{1-\alpha_{t}}\right)=\delta+\sum_{j=1}^{J} \beta_{i} \ln \left(\frac{r_{t-j}}{w_{t-j}}\right)-\left(\frac{\gamma}{1-\gamma}\right) \ln \left(\frac{r_{t}}{w_{t}}\right)+\varepsilon_{t} .
$$

Equation (6) will serve as the basis for our regressions reported below in Section 4.

Note that if induced innovation works either through relative factor augmentation, $\left(A_{K} / A_{L}\right)$ or the weighting of effective factors $(\theta)$, we have a clear prediction about the sign on the partial effects of lagged $(\log )$ price ratios $\left(\beta_{i}\right.$ for $\left.i=1, \ldots, I\right)$ that is conditional on the value of the elasticity of substitution $(\sigma)$. Assume that $0<\sigma<1$ such that $\gamma=1-\frac{1}{\sigma}$ is negative and,

$$
0<\left(\frac{1}{1-\gamma}\right)<1 \quad ; \quad-1<\left(\frac{\gamma}{1-\gamma}\right)<0 .^{6}
$$

Now assume that lagged values of $(r / w)$ have been high. Producers will wish to economize on the relatively expensive factor $(K)$. What sort of innovation will this induce in terms of the production function parameters? What will this imply for the signs on the $\beta_{i} \mathrm{~s}$ ?

First consider the case of factor augmentation. In a neoclassical production function such as (1), it is the ratio of effective factors, $\left(A_{K} K / A_{L} L\right)$, that matters, all else equal. If producers wish

\footnotetext{
${ }^{6}$ This represents the existing consensus in the literature. For examples, Caballero (1994), Caballero et al. (2005), Chirinko et al (1999 \& 2007) and Antràs (2004). Also, Chirinko (2008) provides a review.
} 
to reduce their capital to labor ratio, $(K / L)$, they can work towards this goal by increasing $A_{K}$ relative to $A_{L}$, i.e., through relative capital augmentation. Since $-1<\left(\frac{\gamma}{1-\gamma}\right)<0$, we can predict that $\beta_{i}<0$ for $i=1, \ldots, I$.

Second, consider the case of effect factor weighting. If lagged values of $(r / w)$ have been high, producers can decrease the relative need for $K$ by innovating to increase $\left(\frac{\theta}{1-\theta}\right)$. Since $0<\left(\frac{1}{1-\gamma}\right)<1$ we can predict, in this case as well, that $\beta_{i}<0$ for $i=1, \ldots, I$.

Alternatively, while for $0<\sigma<1$ we would expect the coefficients on lagged (log) factor price ratios to be negative, the coefficient on the contemporaneous price ratio is $-\left(\frac{\gamma}{1-\gamma}\right)$ which we would expect to be positive since $-1<\left(\frac{\gamma}{1-\gamma}\right)<0$. Therefore, for $0<\sigma<1$, we would expect that the coefficients on lagged versus contemporaneous price ratio terms to be of different signs. While we focus in this paper on induced innovation as a determinant of capital's shares, it is not the only determinant proposed by economists. For example, characteristics of the labor market may be important determinants of capital's shares. Labor contracts or employment insurance may alter the distribution of income across productive factors (Gomme and Greenwood (1995); Boldrin and Horvath (1995)). Alternatively, capital's share may be a function of the bargaining power of labor (Bental and Demougin, 2008). We will argue that our results below support the induced innovation hypothesis. However, we cannot make strong statements regarding the inconsistency of the results with alternative hypotheses. 


\section{Data}

The KLEM database combines sectoral data from the US Bureau of Labor Statistics and the US Bureau of Economic Analysis for 35 US sectors. The data are annual with observations from 1960 to 2005 . Variables include the quantity of output $(Q)$ and the price of output $\left(P_{Q}\right)$; the quantity and price of capital services $\left(Q_{K}\right.$ and $\left.P_{K}\right)$; the quantity and price of labor inputs $\left(Q_{L}\right.$ and $\left.P_{L}\right)$; the quantity and price of energy inputs $\left(Q_{E}\right.$ and $\left.P_{E}\right)$; and the quantity and price of materials inputs $\left(Q_{M}\right.$ and $\left.P_{M}\right)$. Dividing service values by prices yields the quantities $K, E$, and $M$.

Value added is computed for each industry, $i$, as $V A_{i}=Q_{i} \cdot P_{Q, i}-V_{E, i}-V_{M, i}$. Then capital's share in value-added is computed as $\alpha_{i}=S_{K, i} /\left(1-S_{M, i}-S_{E, i}\right)$ where $S_{X, i}=V_{X, i} / Q_{i} \cdot P_{Q, i}$ for $X=L, M$, and $E$. Then aggregate value-added is $V A=\Sigma_{i} V A_{i}$ and sector shares in value-added are $w_{i}=V A_{i} / V A$. Table 1 lists the 35 sectors and the net change (from 1960 to 2005) in capital's shares and value-added shares. In many sectors there are clearly substantial (mostly positive) changes in capital's shares. The largest net changes are associated with the coal mining (0.469) and petroleum and coal products $(0.357)$ sectors.

Net changes tend to obscure short-run and medium-run changes in capital's shares. Also in Table 1, there are three broad sector groupings, agriculture, manufacturing, and services, highlighted by shading. ${ }^{7}$ Figure 1A plots the capital's shares of these three broad sectors. (Figure 2B excludes agriculture because its volatility dominates the first graph.) Capital's share in agriculture appears to have at least two periods of trend: increasing before the 1980s and then decreasing thereafter into the mid-1990s. Manufacturing capital's share trends upward during the

\footnotetext{
${ }^{7}$ We focus on here on the broad sector groups to simplify the presentation in tables and figures. In Section 4 below we use observations from the 35 sectors taken separately for the econometric analysis.
} 
1960 to 2005 period; capital's share in services appears basically flat. However, all three series fluctuate considerably. ${ }^{8}$

Aggregate capital's share over the 1960 to 2005 time period (Figure 2) remains in a narrower band than the capital's shares of agriculture or manufacturing due to those sectors shrinking as a share of the economy while service's value-added share increases considerably. Agriculture is a very small share of value-added - about 3 percent on average - during the entire time period. Figure 3 demonstrates how manufacturing and services value-added shares following dramatically different paths. Services increases from just about 40 percent to over 60 percent of the US economy. Manufacturing is the mirror image, decreasing from over 30 percent to less than 20 percent of the economy.

Table 2 summarizes the statistical properties of the broad sector value-added and capital's shares that constitute, together, the evolution of US aggregate capital's share from 1960 to 2005. It presents the means and standard deviations of all the series, as well as the cross-sectoral correlations of both capital's shares and value-added shares.

\section{Econometric Analysis}

Recall the empirical model that we derived from a CES production function and the induced innovation hypothesis:

$$
\ln \left(\frac{\alpha_{t}}{1-\alpha_{t}}\right)=\delta+\sum_{j=1}^{J} \beta_{i} \ln \left(\frac{r_{t-j}}{w_{t-j}}\right)-\left(\frac{\gamma}{1-\gamma}\right) \ln \left(\frac{r_{t}}{w_{t}}\right)+\varepsilon_{t} .
$$

Here we restate (6) as a regression equation:

\footnotetext{
${ }^{8}$ Zuleta and Young (2010) develop a two sector growth model where induced innovation occurs in one sector (manufacturing) while labor and capital are perfect complements in the other sector (services). Their model results in sectoral capital's shares evolving in a pattern very similar to Figure 2B.
} 


$$
\ln \left(\frac{\alpha_{i t}}{1-\alpha_{i t}}\right)=\delta_{j}+\beta_{0} \ln \left(\frac{r_{i t}}{w_{i t}}\right)+\sum_{j=1}^{J} \beta_{j} \ln \left(\frac{r_{i, t-j}}{w_{i, t-j}}\right)+\varepsilon_{i t}
$$

where $i$ indexes sectors and $\beta_{0}=-\left(\frac{\gamma}{1-\gamma}\right)$. Since our data represent a dynamic panel, the $\delta_{i}$ s will be interpreted as sectoral fixed effects. A fixed effects model is most reasonable in this case for various reasons. First, our time series are stationary and we want to control for idiosyncratic industry effects rather than temporal effects. Second, even though we report the results of estimating a random effects model below as a check on robustness, Hausman tests indicate that the fixed effects estimates are more efficient. Lastly, we note the fixed effects models estimated and reported on below do not have significant residual autocorrelation.

From the KLEM data set, our computed capital's shares will serve as $\alpha$. (Labor's share is $(1-\alpha)$.) Our dependent variable in all regressions is the natural $\log$ of $\alpha /(1-\alpha)$. To compute relative factor price ratios, $P_{K}$ and $P_{L}$ will be used, respectively, as $r$ and $w$.

The regressions we report on below all include the contemporaneous $\log$ of $r / w$ and five lagged values of that variable. ${ }^{9}$ Column 1 of Table 3 reports fixed effects regression results of the baseline specification. Since most individual sector capital's shares increase on net over the 1960 to 2005 time period, column 2 also reports results when a time trend is included. Again, this time trend may proxy for trends in technology that are not induced by relative factor prices. (It may also proxy for trends in non-technical determinants, e.g., decreased bargaining power on the part of labor). In either specification, the coefficient on contemporaneous $\ln (r / w)$ is positive, significant at the 1 percent level, and implies a point estimate of the elasticity of substitution $(\sigma)$

\footnotetext{
${ }^{9}$ Both the Akaike and Schwarz criteria (AIC and SIC respectively) continuously decrease through the inclusion of 20 lagged terms. Such a large number of lags is unreasonable for a panel where $T=46$. Also, a clear pattern emerges where the first two lagged terms of $\ln (r / w)$ and last lagged term have negative and significant estimated partial effects; all coefficients on intermediate lags are not significant. We report five lags based on a minimized SIC when a time trend is included. In regards to induced innovation, the most interesting finding is the robustness of a negative effect associated with the first two lags.
} 
between 0.274 and 0.352 . These point estimates are qualitatively consistent with the consensus view that US $\sigma$ is less than unity (Chirinko, 2008). ${ }^{10}$

Relevant to the induced innovation hypothesis, the coefficients on the first and second lags of $\ln (r / w)$ are always negative at better than the 5 percent level of significance. They are of the opposite sign of the coefficient on contemporaneous $\ln (r / w)$. Given that $\sigma$ is estimated to be less than zero, the opposite signs are consistent with induced innovation.

The third and fourth lags of $\ln (r / w)$ are not associated with statistically significant coefficient estimates. The coefficient on the fifth lag is statistically significant and negative at better than the 1 percent level when no time trend is included (column 1). However, the inclusion of a time trend decreases the absolute value of the point estimate decreases by nearly 80 percent (column 2). Statistical significance also decreases; the p-value is about 8.5 percent. This change in the size and significance of the fifth lag term due to inclusion of a time trend carries through all of our subsequent regression results. Because of this, the estimated effects of lags one and two of $\ln (r / w)$ appear to be the more interesting results in regards to induced innovation.

Returning for a moment to the statistically significant time trend, recall the relationship (5), derived from the CES production function:

$$
\left(\frac{1}{1-\gamma}\right) \ln \left(\frac{\theta_{t}}{1-\theta_{t}}\right)+\left(\frac{\gamma}{1-\gamma}\right) \ln \left(\frac{A_{K t}}{A_{L t}}\right)=\delta+\sum_{j=1}^{J} \beta_{i} \ln \left(\frac{r_{j-i}}{w_{j-i}}\right)+\varepsilon_{t},
$$

The time trend is positive and the coefficient point estimate on contemporaneous $(r / w)$ implies that $\gamma$ is negative; thus $(\gamma /(1-\gamma))$ is negative. One way, then, to account for the positive time trend is that there is net labor-augmentation over time, i.e., $\left(A_{K} / A_{L}\right)$ is falling over time. This

\footnotetext{
${ }^{10}$ The range of existing $\sigma$ estimates covers much of the (exclusive) range from zero to unity. Chirinko and Mallick (2007) is one recent example of an estimate (0.33) quantitatively very close to our findings.
} 
would be a not unreasonable conclusion and consistent with the well-known necessary condition for balanced growth in the neoclassical growth model (Jones and Scrimgeour, 2008).

Columns 3 and 4 of Table 3 report random effects results for specifications analogous to those for which columns 1 and 2, respectively, report results. A random effects model may be appropriate because while relevant cross-sectional unit is a sector, e.g., input price data for that sector comes largely from US Current Population Survey (CPS) data across establishments. Each survey is filled out with some unavoidable subjectivity on the part of those completing the survey. Therefore, sectoral effects may be random. On the other hand, we have data on all sectors in the population. Also, recall the arguments from above in favor of fixed effects including, importantly, the results of Hausman tests. Therefore, we view the Column 3 and 4 results as a robustness check. In any case, no result changes in a meaningful way either qualitatively or quantitatively. The random effects results are essentially identical to the fixed effects results.

An immediate concern with our regressions is that they constraint the coefficients across sectors. This may be particularly implausible in regards to sectoral elasticity of substitutions. In this case, the variation across coefficients would be systematic, not random. ${ }^{11}$ To ameliorate this potential problem, we interact the effect of contemporaneous $\ln (r / w)$ with two dummy variables representing the broad sector groups of manufacturing and services. In other words, we modify our specification in the following way:

$$
\begin{aligned}
& \ln \left(\frac{1-\alpha_{i t}}{\alpha_{i t}}\right)=\delta_{j}+\beta_{0} \ln \left(\frac{r_{i t}}{w_{i t}}\right)+\beta_{M 0} D_{M, i t} \ln \left(\frac{r_{i t}}{w_{i t}}\right)+\beta_{S 0} D_{S, i t} \ln \left(\frac{r_{i t}}{w_{i t}}\right), \\
& +\sum_{j=1}^{J} \beta_{j} \ln \left(\frac{r_{i, t-j}}{w_{i, t-j}}\right)+\varepsilon_{i t}
\end{aligned}
$$

${ }^{11}$ This is, incidentally, a good argument for preferring a fixed effects model. 
where $D_{M, i t}\left(D_{S, i t}\right)=1$ if $i$ is a manufacturing (services) sector; 0 otherwise. This specification at least allows the elasticity of substitution to differ systematically for each of these two broad sectors relative to the residual sectors. ${ }^{12}$

Columns 5 and 6 report fixed effects results for specification (9) without and with, respectively, a time trend added. The results are largely unchanged save for the fact that the general point estimate of $\sigma$ increases to between 0.356 and 0.440 . This is due to the fact that the manufacturing interaction is positive and statistically significant at better than the 1 percent level. This implies that the elasticity of substitution in manufacturing is slightly lower: between 0.243 and 0.315 . (The services interaction term is much smaller and never statistically significant.) Importantly, the coefficients on the first and second lags of $\ln (r / w)$ are always negative and significant at better than the 95 percent level.

As one more robustness check, column 7 reports the same regression as column 6 except that the natural log of aggregate (i.e., the sum total across industries) value-added is included as a variable. Several authors (e.g., Boldrin and Horvath (1995), Gomme and Greenwood (1995), and Young (2004)) have noted that capital's share exhibits weakly procyclical behavior. However, controlling for aggregate output has nearly no effect on our results despite the fact that its coefficient estimate is statistically significant at better than the 1 percent level. Furthermore, taking into account all of the other regressors, the estimated sign on aggregate value added is negative (-0.114). This can be contrasted to a fixed effects regression of our dependent variable on only (log of) total value-added. In that case the coefficient estimate is positive $(0.110)$ and

\footnotetext{
${ }^{12}$ We also explored a specification with an agriculture interaction dummy as well. However, agriculture is only a single sector (1) so there is a very small number of observations (41 using the five lags) available to estimate the interaction term. Also, the estimated agriculture interaction term implies a negative $\sigma$. Since this result is nonsensical and, importantly, none of the other coefficients reported in columns 5 and 6 below change in an economically or statistically significant was, we do not report those results.
} 
significant at better than the 1 percent level. Indeed, the coefficient is nearly the mirror image of that reported in column 7 of Table 3 .

To summarize the results reported in Table 3, (a) the coefficient estimates on contemporaneous $\ln (r / w)$ are positive, statistically significant, and consistent with quantitatively reasonable estimates of the US elasticity of substitution between labor and capital ( $\sigma$ ); (b) negative, statistically significant effects associated with the first and second lags of $\ln (r / w)$ are robust across estimation techniques, inclusion of a time trend, and broad sector interactions; (c) the elasticity of substitution estimates combined with the opposite signs of contemporaneous versus lagged $\ln (r / w)$ effects is consistent with the induced innovation hypothesis.

Since we, and most of the literature, estimate US $\sigma$ to be less than unity, an examination of industry-level $\ln (r / w)$ 's over time lends intuitive plausibility to the induced innovation story. As displayed in Figure 4, industry factor price ratios are typically decreasing during the 1960 to 2005 time period. Since,

$$
\sigma=-\frac{d \ln (K / L)}{d \ln (r / w)}
$$

and $0<\sigma<1$, all else equal we would expect that as $(r / w)$ falls the capital to labor ratio $(K / L)$ rises but not proportionately. Referring back to (2), capital's shares should be falling. Since we know that this is not the case, induced labor-saving innovations are a reasonable countervailing force.

\section{Conclusions}

In this paper we used a production function framework to derive testable implications for the induced innovation hypothesis. Capital's share of income is shown to be a function of both contemporaneous and lagged factor price ratios. The elasticity of substitution between labor and 
capital is implied by the value of the coefficient on the contemporaneous price ratio. The value of the elasticity of substitution, in turn, tells us the predicted sign of coefficients on lagged price ratios.

We bring these testable implications to a panel of 35 US industries with annual observations from 1960 to 2005. A monotonic transformation of capital's share is our dependent variable. The estimated coefficient on the contemporaneous factor price (of labor over that of capital) ratio implies an elasticity of substitution less than unity. This is consistent with the consensus view from the literature and implies that the coefficients on lagged factor price ratios should be negative. Indeed, our estimates of these coefficients are negative and statistically significant. These estimated induced innovation effects are robust to both fixed effects and random effects estimation techniques; inclusion or exclusion of a time trend; controlling for different elasticities of substitution in manufacturing versus services; and the inclusion of aggregate value-added to control for cyclical effects.

Despite the renewed interest in the theory of induced, factor-saving innovations (e.g., Zeira (1998), Acemoglu (2002), Boldrin and Levine (2002), Funk (2002), Zuleta (2008a) and Zuleta and Young (2010)), there is a paucity of formal evidence. Recent studies are often focused on a single industry (e.g., Thirtle et al. (2002) and Liu and Shumway (2009) for agriculture). On the other hand, a recent Popp (2002) uses patent data to link changes in energy prices to energy-saving innovation. However, our study is, to our knowledge, unique in being an economy wide study of induced innovation, based on a production function framework, and focused on the two major productive factors: capital and labor.

Empirical important induced innovation effects are not only supporting evidence for the theories cited above. If they exist, as suggested by our results, they may have important policy 
implications. For example, the long-run neutrality; short-run non-neutrality of monetary policy is a mainstay of macroeconomics. However, monetary policy may, by affecting interest rates, alter relative factor prices for sustained periods of time. One interesting question is: to what extent does such policy induce innovation with lasting effects on the economy? This is just one interesting and related question and we leave its answer to future research. 


\section{References}

Acemoglu, D. 2002 Directed technical change. Review of Economic Studies 69 (4): 781-809.

Ahmad, S. 1966. On the theory of induced invention. The Economic Journal 76 (302): 344-357.

Bental, B., Demougin, D. 2008. Do factor shares reflect technology? Journal of Macroeconomics 30 (3): 1329-1334.

Binswanger, H. 1974. A Microeconomic Approach to Induced Innovation. The Economic Journal 84 (336): 940-958.

Boldrin, M., Horvath, M. 1995. Labor contracts and business cycles. Journal of Political Economy 103 (5): 972-1004.

Boldrin, M., Levine, D. K. 2002. Factor saving innovation. Journal of Economic Theory 105 (1): 18-41.

Caballero, R. J. 1994. Small sample bias and adjustment costs. Review of Economics and Statistics 76 (1): 52-58.

Caballero, R. J., Engel, Eduardo, M.R.A., Haltiwanger, J. C. 1995. Plant-level adjustment and aggregate investment dynamics. Brookings Papers on Economic Activity 2 (2): 1-39.

Chirinko, R. S. 2008. $\sigma$ : the long and short of it. Journal of Macroeconomics 30 (2): 671-686.

Chirinko, R. S., Fazzari, S. M., Meyer, A. P. 1999. How responsive is business capital formation to its user cost? an exploration with micro data. Journal of Public Economics $4(1): 3-80$.

Chirinko, R. S., Mallick, D. 2007. The substitution elasticity, growth theory, and the low-pass panel model. Emory University. 
Chirinko, R. S., Fazzari, S. M., Meyer, A. P. 2007. That elusive elasticity: a long-panel approach to estimating the price sensitivity of business capital. Emory University.

Cobb, C., Douglas, P. H. 1928. A theory of production. The American Economic Review 18 (\#): 139-165.

Drandakis, E. M., Phelps, E.S. 1966. A model of induced invention, growth and distribution. The Economic Journal 76 (304): 823-840.

Funk, P. 2002. Induced innovation revisited. Economica 69 (272): 155-171.

Garrido Ruiz, C. 2005. Are factor shares constant? an empirical assessment from a new perspective. Working Paper (http://www.eco.uc3m.es/temp/jobmarket/jmp_C_Garrido.pdf).

Gomme, P., Greenwood, J. 1995. On the cyclical allocation of risk. Journal of Economic Dynamics and Control 19 (1-2): 91-124.

Jones, C. I., Scrimgeour, D. 2008. The steady-state growth theorem: a comment on Uzawa (1961). Review of Economics and Statistics 90 (1): 180-182.

Jorgenson, D. W. 2007. 35 Sector KLEM

(http://dvn.iq.harvard.edu/dvn/dv/jorgenson/faces/study/StudyPage.xhtml?studyId=18782).

Jorgenson, D. W., Gollop, F. M., Fraumeini, B. 1987. Productivity and US

Economic Growth. Cambridge: Harvard University Press.

Jorgenson, D. W., Stiroh, K. J. 2000. Raising the speed limit: U.S. economic growth in the information age. Brookings Papers on Economic Activity (1): 125-212.

Kaldor, N. 1961. Capital accumulation and economic growth. in The Theory of Capital, Lutz and Hagues (Eds.), New York: St. Martin's Press. 
Kennedy, C. 1964. Induced bias in innovation and the theory of distribution. The Economic Journal 74 (295): 541-547.

Kennedy, C. 1964. A Generalisation of the Theory of Induced Bias in Technical Progress. The Economic Journal 83 (329): 48-57.

Liu, Y., Shumway, C. R. 2009. Induced innovation in U.S. agriculture: time-series, direct econometric, and nonparametric tests. American Journal of Agricultural Economics 91 (1): 224-236.

Popp, D. 2002. Induced innovation and energy prices. American Economic Review 92 (1): 160180.

Samuelson, P. A. 1965. A theory of induced innovation along Kennedy-Weisäcker lines. The Review of Economics and Statistics 47 (4): 343-356.

Sato, R., Beckmann, M. J. 1968. Neutral inventions and production functions. Review of Economic Studies 35 (1): 57-66.

Solow, R. M. 1958. A skeptical note on the constancy of relative shares. American Economic Review 48 (4): 618-31.

Sturgill, B. 2009. Cross-country variation in factor shares and its implications for development accounting. Working Papers 09-07, Department of Economics, Appalachian State University.

Thirtle, C. G., Schimmelpfennig, D. E., Townsend, R. F. 2002. Induced innovation in United States agriculture, 1880-1990: time series tests and an error correction model. American Journal of Agricultural Economics 84 (3): 598-614.

Uzawa, H. 1961. Neutral inventions and the stability of growth equilibrium. Review of Economic Studies 28 (2): 117-124. 
von Weizsäcker, C.C. 1966. Tentative notes on a two sector model with induced technical progress. The Review of Economic Studies. 33 (3): 245-251.

Young, A. T. 2004. Labor's share, biased technical change, and the business cycle. Review of Economics Dynamics 7 (4): 916-931.

Young, A. T. 2010. One of the things we know that ain't so: is US labor's share relatively stable? Journal of Macroeconomics (forthcoming).

Zeira, J. 1998. Workers, machines and economic growth. Quarterly Journal of Economics 113 (4): 1091-1117.

Zuleta, H. 2008. Factor saving innovations and factor income shares. Review of Economic Dynamics 11(4): 836-851.

Zuleta, H. 2008. An empirical note on factor shares. The Journal of International Trade \& Economic Development 17 (3): 379-390.

Zuleta, H., Parada, J., Campo, J. 2008. Capital natural, capital humano y participación de los factores. Una Revisión de los Métodos de Medición del Crecimiento Económico" Documento de Trabajo No .41Universidad del Rosario.

Zuleta, H., Young, A. T. 2010. Labor's shares in a model of induced innovation. Unpublished Manuscript.

Zuleta, H., Garcia, A., Young, A. T. 2010. Factor shares at the sector level, Colombia 19902005. Unpublished Manuscript. ='Sub data (Aggregation)'!\$FN\$3:\$FN\$49 
TABLES

TABLE 1-ChANGE IN INDUSTRy CAPITAL'S AND VALUE-ADDED SHARES: 1960 - 2005

\begin{tabular}{|c|c|c|c|}
\hline Industry & Description & $\begin{array}{c}\text { Change in } \\
\text { Capital's Share }\end{array}$ & $\begin{array}{c}\text { Change in Value- } \\
\text { Added Share }\end{array}$ \\
\hline 1 & Agriculture & 0.156 & -0.019 \\
\hline 2 & Metal Mining & 0.299 & -0.002 \\
\hline 3 & Coal Mining & 0.469 & -0.002 \\
\hline 4 & Oil and Gas Extraction & 0.098 & -0.008 \\
\hline 5 & Non-metallic Mining & 0.204 & -0.002 \\
\hline 6 & Construction & 0.126 & -0.032 \\
\hline 7 & Food and Kindred Products & 0.177 & -0.010 \\
\hline 8 & Tobacco & -0.067 & -0.001 \\
\hline 9 & Textile Mill Products & 0.158 & -0.008 \\
\hline 10 & Apparel & 0.027 & -0.011 \\
\hline 11 & Lumber and Wood & 0.142 & -0.003 \\
\hline 12 & Furniture and Fixtures & 0.001 & -0.001 \\
\hline 13 & Paper and Allied & 0.020 & -0.006 \\
\hline 14 & Printing, Publishing and Allied & 0.133 & -0.005 \\
\hline 15 & Chemicals & 0.160 & -0.004 \\
\hline 16 & Petroleum and Coal Products & 0.357 & 0.002 \\
\hline 17 & Rubber \& Miscellaneous Products & 0.055 & 0.001 \\
\hline 18 & Leather & 0.087 & -0.004 \\
\hline 19 & Stone, Clay, Glass & 0.065 & -0.006 \\
\hline 20 & Primary Metal & 0.254 & -0.016 \\
\hline 21 & Fabricated Metal & 0.217 & -0.013 \\
\hline 22 & Non-electrical Industry & 0.011 & -0.011 \\
\hline 23 & Electrical Industry & 0.087 & -0.008 \\
\hline 24 & Motor Vehicles & -0.096 & -0.008 \\
\hline 25 & Transportation Equip \& Ordinance & 0.098 & -0.009 \\
\hline 26 & Instruments & 0.026 & 0.001 \\
\hline 27 & Miscellaneous Manufacturing & 0.276 & -0.003 \\
\hline 28 & Transportation & 0.117 & -0.021 \\
\hline 29 & Communications & 0.132 & 0.006 \\
\hline 30 & Electrical Utilities & 0.061 & 0.004 \\
\hline 31 & Gas Utilities & 0.018 & -0.003 \\
\hline 32 & Trade & 0.127 & -0.029 \\
\hline 33 & Finance, Insurance \& Real Estate & 0.014 & 0.069 \\
\hline 34 & Services & -0.054 & 0.157 \\
\hline 35 & Government Enterprises & & \\
\hline
\end{tabular}

Notes: Calculated from 35 annual industries' data, 1960 to2005. Capital's share is of annual value added. Shaded areas, from top to bottom, represent "Agriculture," "Manufacturing," and "Services" broad sector groupings. 
TABLES (CONT.)

TABLE 2 - SUMmARY StATISTICS FOR US BROAD SECTORS

\begin{tabular}{|c|c|c|c|}
\hline \multicolumn{4}{|l|}{ Statistic for } \\
\hline \multicolumn{4}{|l|}{ Capital's Share } \\
\hline Mean & 0.298 & 0.334 & 0.502 \\
\hline$\sigma$ & 0.036 & 0.012 & 0.086 \\
\hline$\rho_{x, \text { Manufacturing }}$ & 1.000 & 0.195 & -0.198 \\
\hline$\rho_{x, \text { Services }}$ & 0.195 & 1.000 & 0.352 \\
\hline$\rho_{x, \text { Agriculture }}$ & -0.198 & 0.352 & 1.000 \\
\hline$\Delta_{1960,2005}$ & 0.126 & 0.036 & -0.156 \\
\hline \multicolumn{4}{|l|}{ Value-Added Share } \\
\hline Mean & 0.263 & 0.490 & 0.030 \\
\hline$\sigma$ & 0.041 & 0.070 & 0.007 \\
\hline$\rho_{x, \text { Manufacturing }}$ & 1.000 & -0.981 & 0.912 \\
\hline$\rho_{x, \text { Services }}$ & -0.981 & 1.000 & -0.911 \\
\hline$\rho_{x, \text { Agriculture }}$ & 0.912 & -0.911 & 1.000 \\
\hline$\Delta_{1960,2005}$ & -0.123 & 0.199 & -0.019 \\
\hline \multicolumn{4}{|c|}{$\begin{array}{l}\text { Notes: Data from 35-KLEM database. Methodology described in Jorgenson et al (1987), } \\
\text { Manufacturing includes "Food and Kindred Products," Tobacco," "Textile Mill Products," } \\
\text { "Apparel," "Lumber and Wood," "Furniture and Fixtures," "Paper and Allied," "Print, Publishing } \\
\text { \& Allied," "Chemicals," "Petroleum and Coal Products," "Rubber and Miscellaneous Products," } \\
\text { "Leather," "Stone, Clay and Glass," "Primary Metal," "Fabricated Metal," "Non-electrical } \\
\text { Industry," "Electrical Industry," "Motor Vehicle," "Transportation Equipment and Ordinance," } \\
\text { "Instruments," and "Miscellaneous Manufacturing" industries. Services include "Services," } \\
\text { "Trade," and "Finance, Insurance and Real Estate" industries. }\end{array}$} \\
\hline
\end{tabular}


TABLE 3 - REgRESSION RESULTS

\begin{tabular}{|c|c|c|c|c|c|c|c|}
\hline Variables & $\begin{array}{l}(1) \\
\text { Fixed } \\
\text { Effects }\end{array}$ & $\begin{array}{c}(2) \\
\text { Fixed } \\
\text { Effects }\end{array}$ & $\begin{array}{c}(3) \\
\text { Random } \\
\text { Effects }\end{array}$ & $\begin{array}{c}(4) \\
\text { Random } \\
\text { Effects }\end{array}$ & $\begin{array}{c}(5) \\
\text { Fixed } \\
\text { Effects }\end{array}$ & $\begin{array}{c}(6) \\
\text { Fixed } \\
\text { Effects }\end{array}$ & $\begin{array}{c}(7) \\
\text { Fixed } \\
\text { Effects }\end{array}$ \\
\hline$r / w$ & $\begin{array}{l}0.647^{* * *} \\
(0.041)\end{array}$ & $\begin{array}{l}0.726^{* * *} \\
(0.032)\end{array}$ & $\begin{array}{l}0.648^{* * *} \\
(0.041)\end{array}$ & $\begin{array}{l}0.726^{* * *} \\
(0.031)\end{array}$ & $\begin{array}{l}0.560^{* * *} \\
(0.050)\end{array}$ & $\begin{array}{l}0.644^{* * *} \\
(0.039)\end{array}$ & $\begin{array}{l}0.644^{* * *} \\
(0.040)\end{array}$ \\
\hline$\sigma$ & 0.352 & 0.274 & 0.352 & 0.274 & 0.440 & 0.356 & 0.356 \\
\hline Manufacturing & & & & & $\begin{array}{c}0.125^{* * *} \\
(0.040)\end{array}$ & $\begin{array}{c}0.112^{* * *} \\
(0.031)\end{array}$ & $\begin{array}{c}0.108^{* * *} \\
(0.031)\end{array}$ \\
\hline Services & & & & & $\begin{array}{c}0.017 \\
(0.068)\end{array}$ & $\begin{array}{c}0.090^{*} \\
(0.089)\end{array}$ & $\begin{array}{l}0.093^{*} \\
(0.054)\end{array}$ \\
\hline$\sigma_{\text {Manufacturing }}$ & & & & & 0.315 & 0.243 & 0.248 \\
\hline$\sigma_{\text {Services }}$ & & & & & 0.423 & 0.266 & 0.263 \\
\hline$r / w(-1)$ & $\begin{array}{c}-0.155^{* * *} \\
(0.053)\end{array}$ & $\begin{array}{c}-0.121^{* * *} \\
(0.042)\end{array}$ & $\begin{array}{c}-0.155^{* * *} \\
(0.053)\end{array}$ & $\begin{array}{c}-0.121^{* * *} \\
(0.042)\end{array}$ & $\begin{array}{c}-0.153^{* * *} \\
(0.053)\end{array}$ & $\begin{array}{c}-0.119^{* * *} \\
(0.042)\end{array}$ & $\begin{array}{c}-0.118^{* * *} \\
(0.042)\end{array}$ \\
\hline$r / w(-2)$ & $\begin{array}{l}-0.151^{* * *} \\
(0.053)\end{array}$ & $\begin{array}{l}-0.096^{* *} \\
(0.042)\end{array}$ & $\begin{array}{c}-0.151^{* * *} \\
(0.053)\end{array}$ & $\begin{array}{l}-0.096^{* *} \\
(0.042)\end{array}$ & $\begin{array}{l}-0.149^{* * *} \\
(0.053)\end{array}$ & $\begin{array}{l}-0.095^{* *} \\
(0.042)\end{array}$ & $\begin{array}{l}-0.094^{* * *} \\
(0.042)\end{array}$ \\
\hline$r / w(-3)$ & $\begin{array}{c}0.005 \\
(0.054)\end{array}$ & $\begin{array}{c}0.041 \\
(0.043)\end{array}$ & $\begin{array}{c}0.005 \\
(0.054)\end{array}$ & $\begin{array}{c}0.041 \\
(0.043)\end{array}$ & $\begin{array}{c}0.007 \\
(0.054)\end{array}$ & $\begin{array}{c}0.043 \\
(0.042)\end{array}$ & $\begin{array}{c}0.041 \\
(0.042)\end{array}$ \\
\hline$r / w(-4)$ & $\begin{array}{l}-0.046 \\
(0.055)\end{array}$ & $\begin{array}{l}-0.025 \\
(0.043)\end{array}$ & $\begin{array}{l}-0.046 \\
(0.055)\end{array}$ & $\begin{array}{l}-0.025 \\
(0.043)\end{array}$ & $\begin{array}{l}-0.045 \\
(0.055)\end{array}$ & $\begin{array}{l}-0.026 \\
(0.043)\end{array}$ & $\begin{array}{l}-0.029 \\
(0.043)\end{array}$ \\
\hline$r / w(-5)$ & $\begin{array}{l}-0.257^{* * *} \\
(0.042)\end{array}$ & $\begin{array}{l}-0.058^{*} \\
(0.034)\end{array}$ & $\begin{array}{l}-0.257^{* * *} \\
(0.042)\end{array}$ & $\begin{array}{l}-0.058^{*} \\
(0.034)\end{array}$ & $\begin{array}{l}-0.255^{* * *} \\
(0.042)\end{array}$ & $\begin{array}{l}-0.058^{*} \\
(0.034)\end{array}$ & $\begin{array}{l}-0.066^{* *} \\
(0.034)\end{array}$ \\
\hline Time Trend & & $\begin{array}{l}0.018^{* * *} \\
(0.001)\end{array}$ & & $\begin{array}{l}0.018^{* * *} \\
(0.001)\end{array}$ & & $\begin{array}{l}0.018^{* * *} \\
(0.001)\end{array}$ & $\begin{array}{l}0.026^{* * *} \\
(0.003)\end{array}$ \\
\hline $\begin{array}{l}\text { Aggregate Value- } \\
\text { Added }\end{array}$ & & & & & & & $\begin{array}{l}-0.114^{* * *} \\
(0.042)\end{array}$ \\
\hline Observations & 1435 & 1435 & 1435 & 1435 & 1435 & 1435 & 1435 \\
\hline AIC & 0.050 & -0.434 & & & 0.044 & -0.441 & -0.449 \\
\hline SIC & 0.200 & -0.279 & & & 0.202 & -0.279 & -0.284 \\
\hline $\mathrm{R}^{2}$ & 0.915 & 0.948 & 0.239 & 0.0528 & 0.916 & 0.948 & 0.949 \\
\hline
\end{tabular}

Notes: Robust standard errors in parentheses; ${ }^{* * *} \mathrm{p}<0.01,{ }^{* *} \mathrm{p}<0.05,{ }^{*} \mathrm{p}<0.1$. 


\section{FIGURES}

FiguRE 1A - US BROAD SECTORAL CAPITAL's SHARES

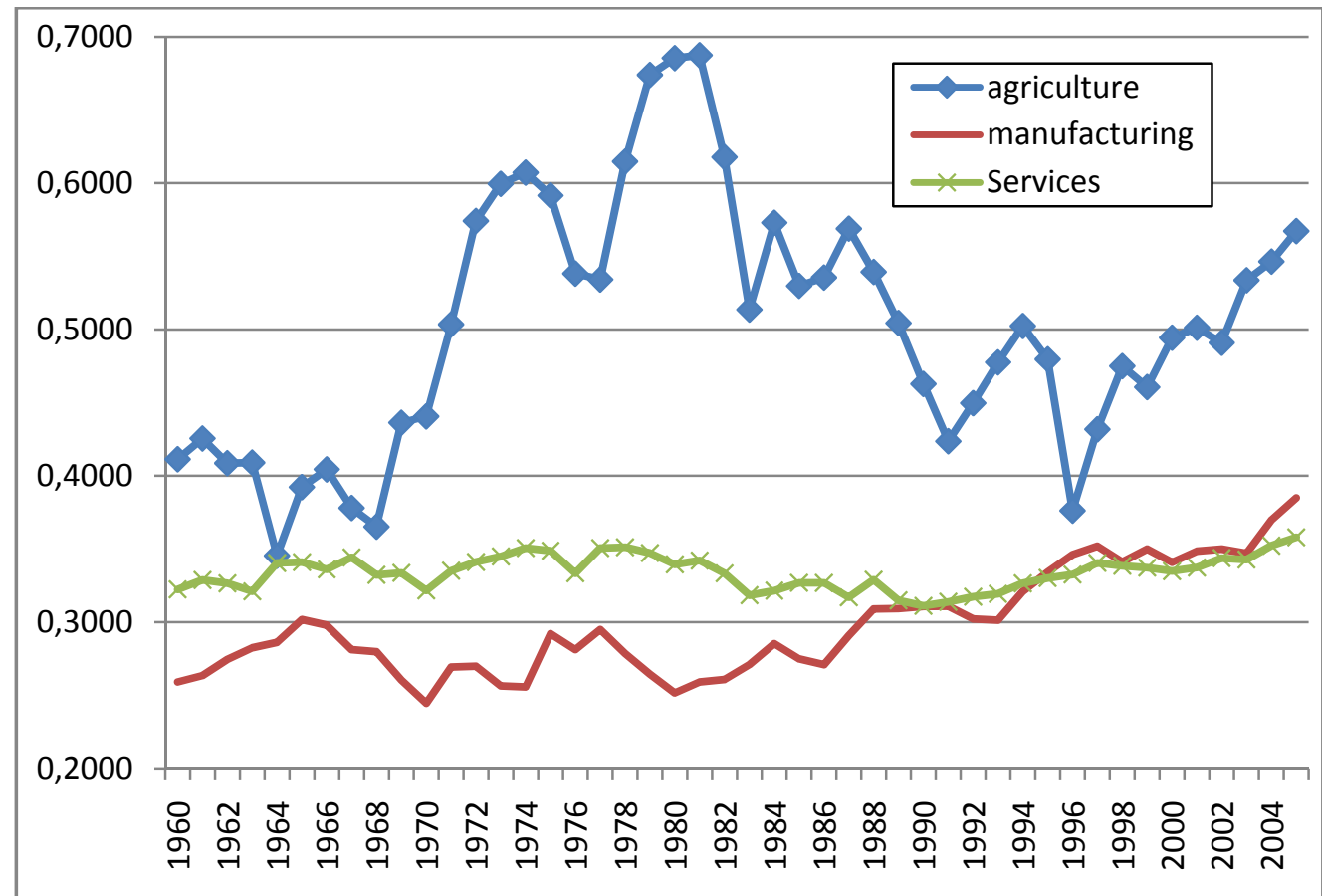

Figure 1B - US Broad Sectoral Capital's Shares (Excluding Agriculture)

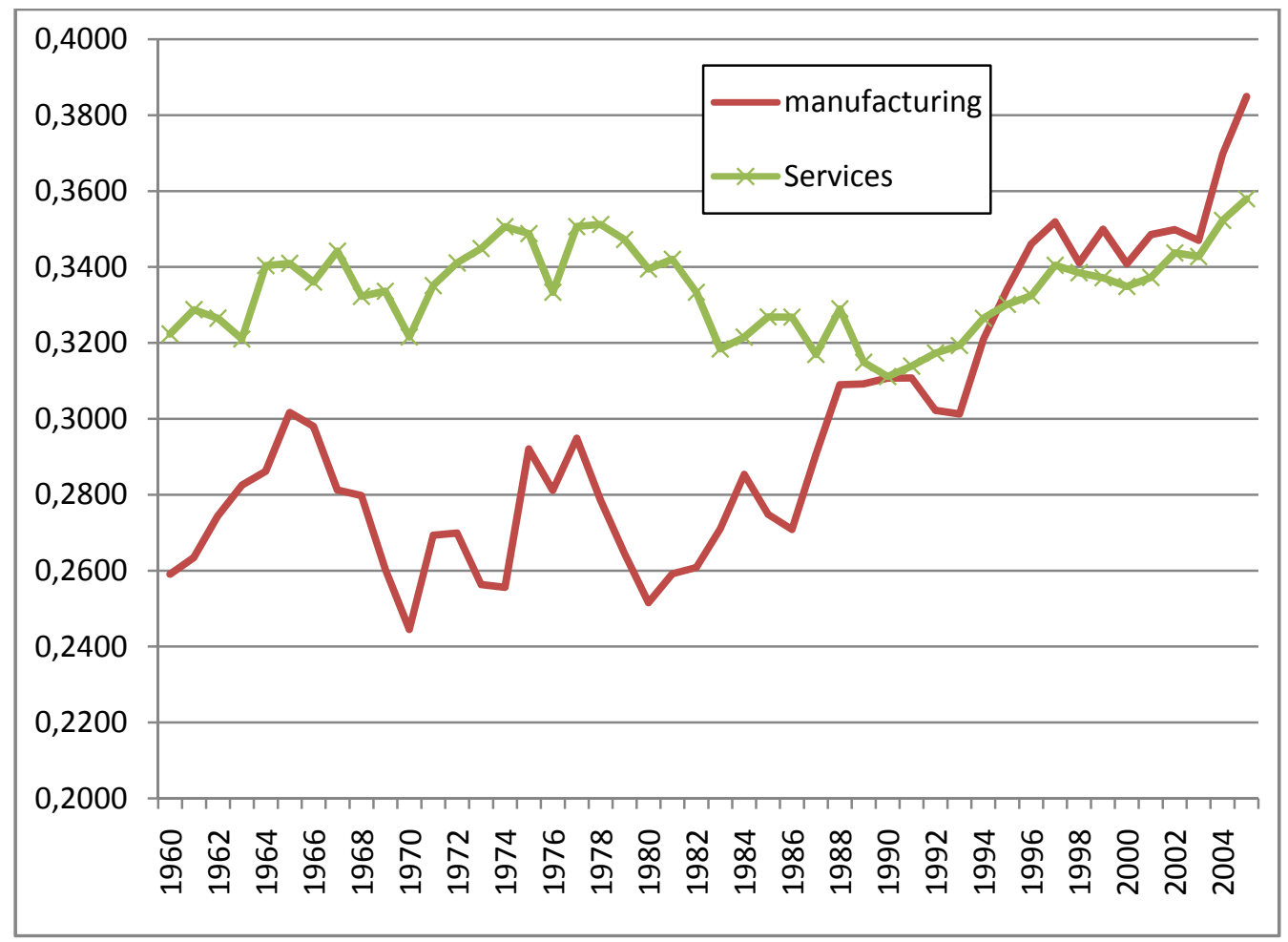




\section{FigURES (CONT.)}

Figure 2 - US AgGregate CAPITAL's SHARE

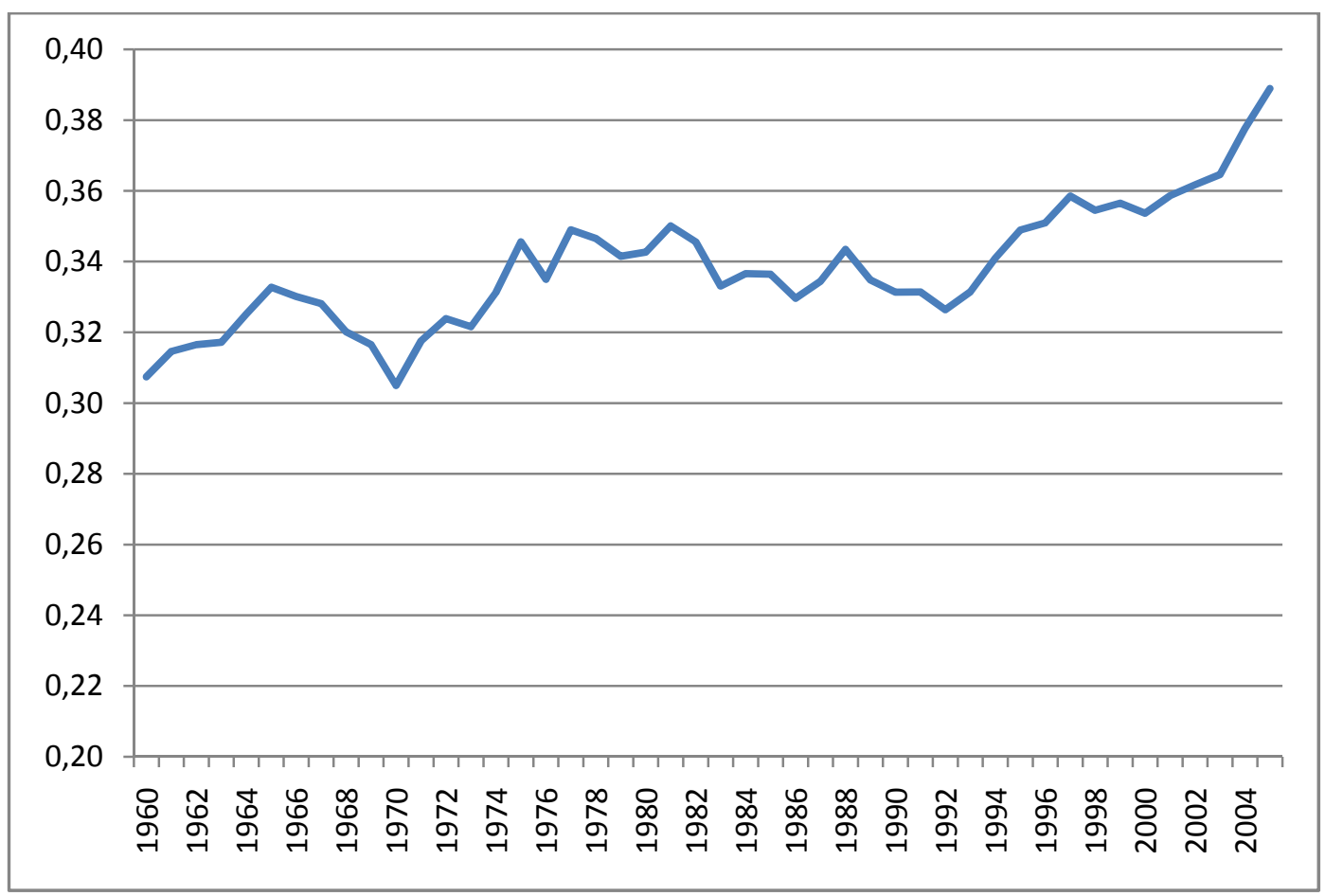

Figure 3 - US Manufacturing AND Services Sector Value-Added SHares

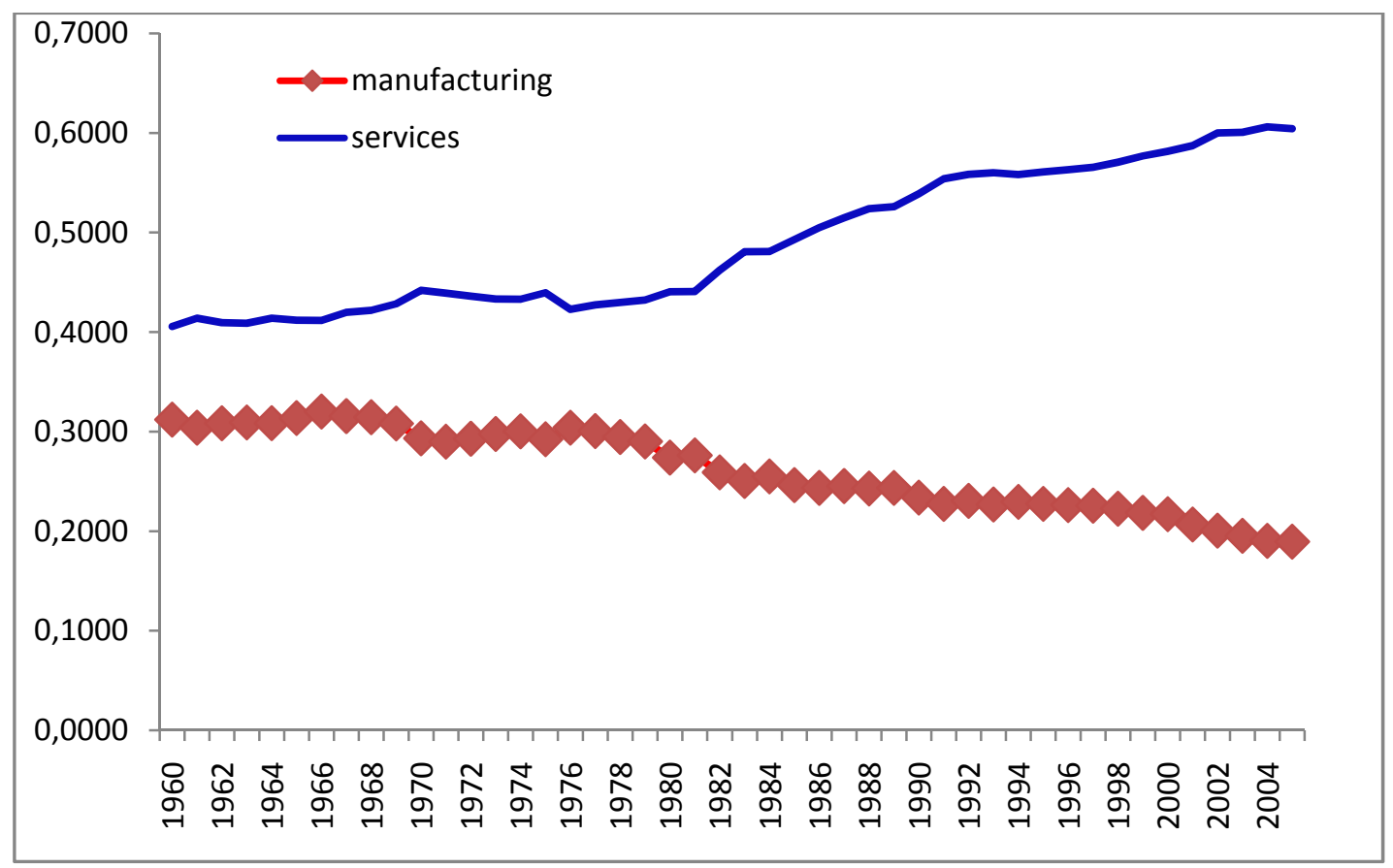




\section{FIGURES (CONT.)}

Figure 4 - NAtUral Log OF FaCtor Price Ratio $(r / w)$ FOR 35 US Industries

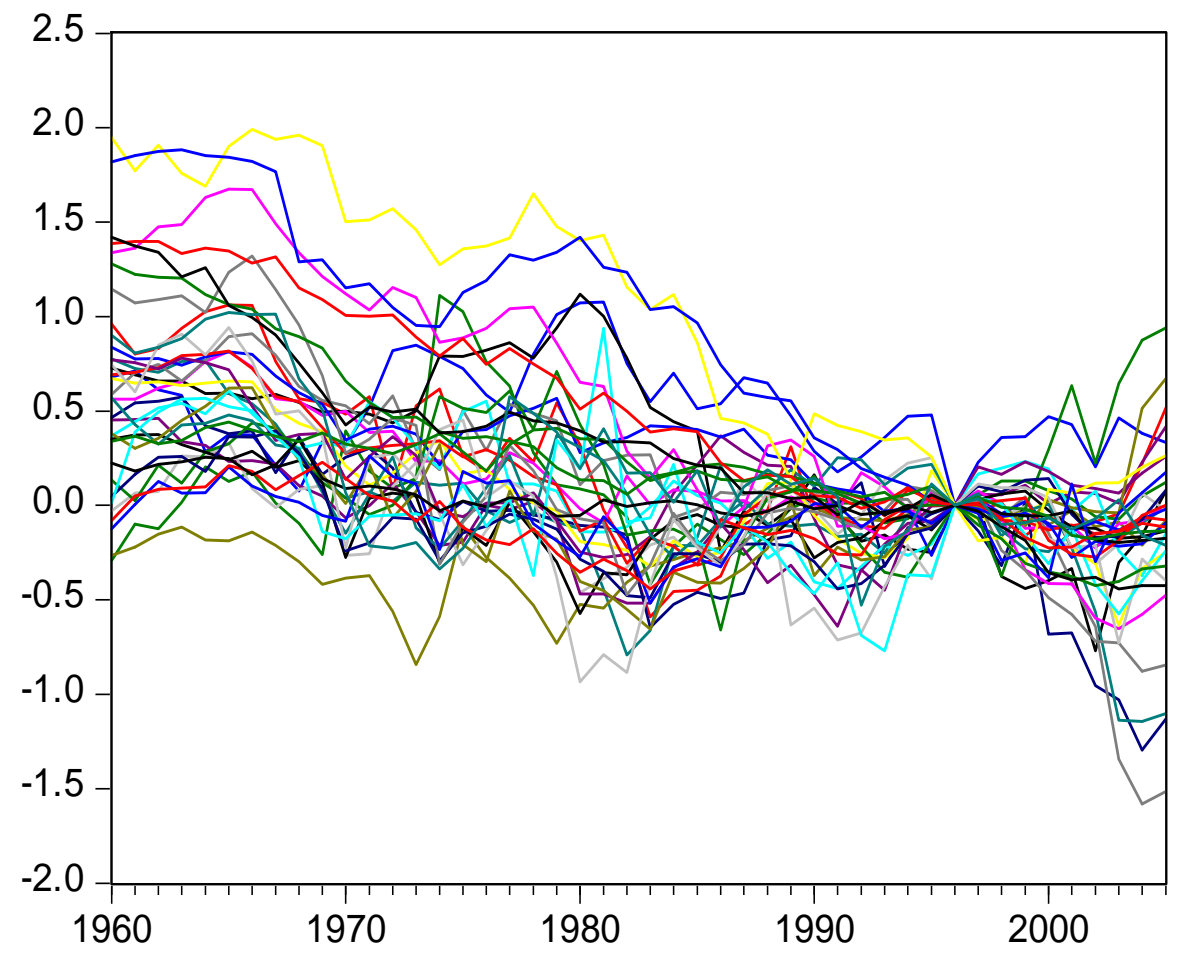

